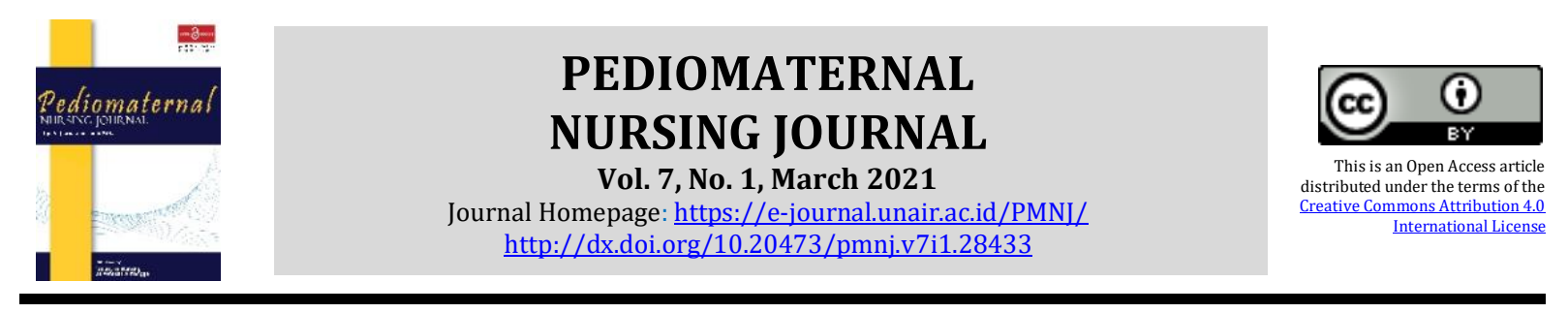

Scientific Editorial

\title{
EDITORIAL
}

\section{Community Adaptation to Photobiomodulation Near-Infrared Based on Post-Partum Culture Care}

\author{
Dr. Rosnani Rosnani, S. Kp., M. Kep., Sp. Mat. \\ Prodi D III Keperawatan Poltekkes Kemenkes Palembang, Palembang, Indonesia. \\ Phone: +62 82178070107, email: rosnani@poltekkespalembang.ac.id
}

Cultural relativity is an ethical challenge for global health workers in providing health services. Cultural relativity is ethical standards based on local culture and unique values in society. Clinical nursing and research with a cultural context can be designed by building local or global partnerships (WHO, 2015). The results of research in the city of Palembang, postpartum mothers use the services of a massage therapist to perform treatment at home (Setyowati \& Rosnani, 2019) or traditional midwife (Anderson et al., 2018). This causes mothers to have a great opportunity to receive advice from a therapist or family (Kronborg et al., 2015).

Advice from the therapist and family is a dominant factor in the mother's decision to seek treatment. Maternal characteristics affect the mother's clinical condition (Giraldo Gartner et al., 2016). The results of the study show that the home visit program is only provided for mothers who are at risk (Mccabe et al., 2012). The home visit program during this pandemic is not a priority for maternal services from the Public Health Center.
Innovative practice of post-partum care culture with Photobiomodulation Nearinfrared (PBM NIR) technology, used with hygienic principles, resources that are easy to obtain and easy for mothers to use. Health technology allows individuals to choose or receive offers to solve problems in their health care. With the knowledge of nurses about people's perceptions of the use of technology, a tool was developed to replace traditional heating techniques (Alligood, 2014).

The PBM NIR intervention has an effect on the mothers psychosocial. Mother refused when asked for approval for the PBM NIR intervention. They also cancel agreements that have been made previously. This is because mothers need trust (a sense of trust first before they receive an intervention. A trusting relationship between nurses and patients can have a therapeutic impact on interventions). (Basit et al., 2015). The thing that becomes a challenge for transcultural nursing care is when there is distrust and suspicion from mothers about perinatal care (Muzik, Kirk, Alfafara, Jonika, \& Waddell, 
2016). This causes mothers to seek help through family and religion, rather than medical services. For this reason, a familycentered approach to care is needed, recognition of relatives and members of the mother's social network as a guide in the care process. Cultural innovations can be accepted if needed and recommended by parents or families. This is related to the mother's trust in the care giver.

The findings of this study in the form of PBM NIR interventions have provided tangible evidence that nurses modify the client's culture to continue to be applied by the community without losing the values and culture adopted. Mother's acceptance of this intervention can also be caused by the shape of the tool that resembles household equipment, thereby reducing the mother's fear of trying to do this intervention. Customs can be learned, maintained and can be passed on to the next generation. These beliefs and practices can become a new culture for them (Sivri \& Karataş, 2015).

This research product can also be used by post-partum mothers who have a tradition of using heating techniques in their care. Mothers can still carry out their traditions, when they have limitations, such as being far from massage shamans and having difficulty obtaining traditional heating devices. The application of this research is the implementation of culturally sensitive nursing care (Sein, 2013). Researchers understand the context in which women can accept new practices for behavior change if they are more realistic and relevant (Choudhury \& Ahmed, 2011). For example, middle class women in urban areas, manifest their behavior in postpartum care practices with more dominant modernization thinking (Liamputtong, 2004). Therefore, traditional postpartum beliefs and practices with technology can be more accepted by them. The practice of post-partum care with PBM NIR can be socialized to mothers (Lamadah, 2013). Mothers who no longer live in their original area or far from their cultural environment, they can still apply their cultural values and customs.

\section{References:}

Alligood, M. R. (2014). Nursing Theorists and Their Work. Elsevier.
Anderson, F. W. J., Johnson, T. R. B., \& Vries, R. De. (2018). Best Practice \& Research Clinical Obstetrics and Gynaecology Global Health Ethics: The Case of Maternal and Neonatal Survival. Best Practice \& Research Clinical Obstetrics \& Gynaecology, 43(2017), 125-135. https://doi.org/10.1016/j.bpobgyn.20 17.02.003

Basit, M., Mahmudah, R., \& Dewi, I. S. (2015). The Correlation of Therapeutic Comunication Witk Client Trust Againt Nurses in Inpatient at Sari Mulia Hospital Banjarmasin. Dinamika Kesehatan, 6(1), 63-72.

Choudhury, N., \& Ahmed, S. M. (2011). Maternal Care Practices Among the Ultra Poor Households in Rural Bangladesh : a Qualitative Exploratory Study. BMC Pregnancy and Childbirth, 11(15), $\quad 1-8$. https://doi.org/10.1186/1471-239311-15

Giraldo Gartner, V., Munoz Rondon, C., Buitrago Echverri, M. T., \& Abadia Barrero, y C. E. (2016). Interacciones Entre el Cuidado Doméstico y Hospitalario Durante la Gestación y el Puerperio Entre Mujeres Que Viven en Condiciones Socioeconómicas Adversas Que Asisten a una Clínica de Maternidad en Cartagena , Colombia. Revista Colombiana de Anestesiología, 4(3), 224-229. https://doi.org/10.1016/j.rca.2016.04. 009

Kronborg, H., Harder, I., \& Hall, E. O. C. (2015). First time mothers' experiences of breastfeeding their newborn. Sexual and Reproductive Healthcare, 6(2), 82-87. https://doi.org/10.1016/j.srhc.2014.08 .004

Lamadah, S. M. (2013). Postpartum Traditional Beliefs and Practices among Women in Makkah Al Mukkaramah, KSA. Life Science Journal, 10(4).

Liamputtong, P. (2004). Yu Duan Practices as Embodying Tradition, Modernity and Social Change in Chiang Mai, Northern Thailand. Women \& Health, December, 37-41. https://doi.org/10.1300/J013v40n01

Mccabe, B. K., Potash, D., Omohundro, E., \& Taylor, C. R. (2012). Design and 
Implementation of an Integrated , Continuous Evaluation, and Quality Improvement System for a State-Based Home-Visiting Program. Matern Child Health Jounal, 16, 1385-1400. https://doi.org/10.1007/s10995-0110906-6

Sein, K. K. (2013). Beliefs and Practices Surrounding Postpartum Period Among Myanmar Women. Midwifery, 29(11), 1257-1263.

https://doi.org/10.1016/j.midw.2012. 11.012

Setyowati, S., \& Rosnani, R. (2019). Women' s Efforts to Solve Postpartum Problems Based on The Culture of South Sumatera. Enfermería Clínica, 29(S2),
653-658.

https://doi.org/10.1016/j.enfcli.2019.0 4.100

Sivri, B. B., \& Karataș, N. (2015). Toplumun Kültürel Yönü : Doğum Sonu Dönemde Anne ve Bebek Bakımına Yönelik Yapılan Geleneksel Uygulamalar ve Dünyadan Örnekler. The Journal of Current Pediatrics, 13, 183-194. https://doi.org/10.4274/jcp.50479

WHO. (2015). Strategies Toward Ending Preventable Maternal Mortality ( EPMM ). In Who (Vol. 6736). https://doi.org/ISBN 978924150848 3 